\title{
A Conceptualisation of the Emergence of Infrastructure Investment as a Separate Asset Class
}

\author{
Joseph B. Oyedele \\ Department of Estate Management, Faculty of Environmental Design and Management, \\ Obafemi Awolowo University, Ile_Ife, Osun State, Nigeria \\ Email:;oe_christ2001@yahoo.co.uk
}

Doi:10.5901/ajis.2014.v3n1p213

\begin{abstract}
There is a growing debate over the investment disposition of infrastructure resources and this requires detailed investigation. This mounting debate reflects the growing attraction of infrastructure as a significant investment strategy, particularly among institutional investors such as pension funds and recently the interest of sovereign wealth funds for this asset class has also escalated. This paper argues from a conceptual perspective the emergence of infrastructure as a separate asset class. Its guaranteed sustainability as an asset class is driven by several factors including its resilient characteristics against downturn economic situations and the increasing supply and demand imbalance, largely reflecting the increasing involvement of the private sector in infrastructure investment.
\end{abstract}

Keywords: Infrastructure, Investments, Asset Classes and Diversification Benefits

\section{Introduction}

Is infrastructure a separate asset class? (Indarest, 2009), this question reflects a growing debate over the investment disposition of infrastructure resources and requires detailed investigation. It is not uncommon for infrastructure to be viewed as a subset of commercial real estate or as a substitute for long duration bonds with an embedded inflation hedge, even some professional investors, regard infrastructure as a private equity strategy, with the focus on refinancing and restructuring the business to generate capital gains (RREEF, 2007). This mounting debate reflects the growing attraction of infrastructure investment increased significance, particularly among institutional investors such as pension funds and recently the interest of sovereign wealth funds for this asset class has also escalated. Peng and Newell (2007) argue that these investors in a bid to enhance performance and diversification are now turning to infrastructure which previously was seen as part of their property allocation, this perception is already been established as most private investments in infrastructure have significantly increased and investors are now beginning to identify infrastructure as an asset class enhancing the efficiency of their investment portfolios (Finkenzeller and Dechant, 2009). This view is further expatiated by Hobbs and Lowik (2007) who argue that 'Infrastructure investing' has emerged to be one of the most significant and fastest growing asset classes.

Similarly, the growth and expansion of infrastructure assets are increasingly assuming an international dimension; for instance the sector has developed and matured in Australia and the United Kingdom and is already ascertaining its pathway in Canada and the United States (PCA, 2007). This global infrastructure expansion is expected to continue, driven by the need for infrastructure investment due to decades of severe underinvestment in both economic and social infrastructure assets and networks. Neglected and deteriorating assets, coupled with strong population growth, economic development, and soaring costs and scale of modernizing or replacing infrastructure assets, have facilitated an enormous supply and demand imbalance which is negatively impacting society and communities. Strong economic growth, measured by increasing GDP and increasing wealth among consumers, is likely to spur infrastructure investment, particularly in developing countries (Macquarie, 2007).

The rest of the paper is structured into four sections; Section 2 discusses the investment characteristics and attraction of infrastructure as an investment channel. An investigation of various sources of finance and other assets classes are presented in Section 3. The continued motivation and increasing interest among investors in the infrastructure sector is established by the increasing growth of infrastructure funds, this is expatiated in Section 4 and the concluding remarks is presented in section 5 . 


\section{Investment Characteristics of Infrastructure}

Infrastructure is most commonly conferred in terms of its characteristics - longevity, scale, inflexibility, and higher investment costs - but that is rarely seen as appropriate. Increasingly, its meaning has been shifting from one focusing on physical fixed assets to softer types of infrastructure such as information systems and knowledge bases. Increasingly inter-reliant, society significantly dependent on the smooth operation of a growing range of infrastructure services, though infrastructure is not an end in itself, their quality and provision guarantees the delivery of essential services that enhance economic growth, and contribute to quality of life, including the social well-being, health and safety of citizens, the value of locality and environmental quality (OECD, 2008). Infrastructure is built to facilitate and establish a flow of services, which according to CIDA (2001) must be economically viable and equitably accessed by all levels of society (particularly the poor and women). The quality of infrastructure services significantly expands economic potential and empowers societies to improve living standards, efficiently advancing sustainable growth and expansions.

The attraction of infrastructure as an investment channel is strongly attributed to the several unique characteristics associated with the asset class not only as essential necessity for the community but also the lack of it can adversely affect smooth economic functions and operations. By their nature, infrastructure assets are defensive and possess attractive risk-adjusted returns (Mills, 2007). The high barriers to entry and the monopoly-like characteristics of many infrastructure assets mean that their financial performance is not as sensitive to the economic cycle as many other asset classes. Infrastructure assets are therefore essential resources for sustainable long-term cash flows due to consistent end-user demand and strong competitive positions. The strong competitive position is the result of factors, including: high initial development and construction costs, such as the cost to build roads; required government approvals, which may be difficult or time-consuming to obtain, such as approvals for a network of communications towers, or approvals to lay water pipes under city streets; and long-term exclusive concessions and customer contracts (Macquarie Infrastructure Company, 2009).

Several other infrastructure investment characteristics (Mills, 2007; Beeferman, 2008; Newell and Peng, 2008; Stevens, 2008) include: long duration of infrastructure assets re: operating concessions (e.g., up to 99-year leases); with predictable, stable, long-term contractual protection of revenues, low risk and high income-related returns; Income stream usually backed by government or user-pay schemes; Protection against volatility and inflation; Diversification benefits (risk profile, volatility profile and time horizon different to other asset classes); Social and political benefits (investment is associated with support for community and economic development); Sector growth potential and Low correlation with traditional investments (Table 1). Infrastructure investment returns generally have a relatively low correlation with those from traditional asset classes. Some investment drivers are more closely linked to GDP growth (e.g. ports), while others are more closely related to population growth (e.g. water utilities) (Mills, 2007).

Table 1. Characteristics Associated With Infrastructure and Other Assets Categories

\begin{tabular}{|c|c|c|c|c|}
\hline & Infrastructure & Institutional Bonds & Institutional Real Estate & Private Equity \\
\hline Nature of Asset & $\begin{array}{c}\text { Typically operating company dependent } \\
\text { on control of large physical assets }\end{array}$ & Financial security & Physical Property & Operating Company \\
\hline Asset Availability & $\begin{array}{c}\text { ssset scarcity, many in unique, monopoly } \\
\text { situations }\end{array}$ & $\begin{array}{c}\text { Deep volume in } \\
\text { most markets }\end{array}$ & $\begin{array}{c}\text { Moderate to deep volumes } \\
\text { in most markets }\end{array}$ & Moderate volumes in most markets \\
\hline Acquisition Dynamic & $\begin{array}{c}\text { Competitive tenders, regulatory, } \\
\text { environmental, social and political issues, } \\
\text { often held for long run }\end{array}$ & $\begin{array}{c}\text { Efficient, on-market } \\
\text { purchase }\end{array}$ & $\begin{array}{c}\text { Competitive tenders, } \\
\text { environmental and social } \\
\text { issues common }\end{array}$ & $\begin{array}{c}\text { Competitive tenders, management } \\
\text { buy-outs, negotiated trade sale, } \\
\text { typically medium-term exit strategy }\end{array}$ \\
\hline Liquidity & Moderate & Very high & Moderate in most sectors & moderate \\
\hline Income & $\begin{array}{c}\text { Once assets mature, very stable, } \\
\text { inflation/GDP growth relative. Typically } \\
\text { higher bonds and core real estate }\end{array}$ & $\begin{array}{c}\text { Fixed coupon: } \\
\text { sensitive to interest } \\
\text { rats }\end{array}$ & $\begin{array}{c}\text { Mixture of fixed and } \\
\text { variable interest rate and } \\
\text { sector dependent }\end{array}$ & Typically dominated by capital returns \\
\hline Growth & $\begin{array}{c}\text { Dependent on asset stage: modest (late- } \\
\text { stage) to high (early stage/development) } \\
\text { assets) }\end{array}$ & $\begin{array}{c}\text { Lependent upon asset } \\
\text { characteristics; moderate to } \\
\text { high }\end{array}$ & $\begin{array}{c}\text { Dependent on asset characteristics; } \\
\text { typically high }\end{array}$ \\
\hline Volatility & $\begin{array}{c}\text { Moderate (early stage) to low (late stage) } \\
\text { Low/Moderate }\end{array}$ & $\begin{array}{c}\text { Moderate (market } \\
\text { factors) }\end{array}$ & $\begin{array}{c}\text { High (early stage) to Moderate (late } \\
\text { stage) depending upon industry } \\
\text { sector }\end{array}$ \\
\hline $\begin{array}{c}\text { Typical return } \\
\text { expectation per } \\
\text { annum post fees }\end{array}$ & $\begin{array}{c}\text { Mature portfolio: 7-10\% Development } \\
\text { portfolio }>10 \%\end{array}$ & Approximately 5-7\% & $\begin{array}{c}\text { Core: } ~ 7.9 \% \text { Value added: } \\
\sim 12-18 \% \text { Opportunity: } \\
>18 \%\end{array}$ & Diversified portfolio $>15 \%$ \\
\hline
\end{tabular}

Source: Beeferman (2008) 
Other unique investment characteristics of infrastructure include hybrid potentials, Infrastructure assets share certain features closely related to those of other assets including real estate, fixed income, and private equity, for instance investing in a mature, government regulated utility is analogous to a fixed income investment with the advantage of having a degree of inflation protection (RREEF, 2007). Also similar to private equity, given the equity contribution in investments as well as possible illiquidity risks(PCA, 2007), however, infrastructure also differ from other assets such as bonds, equities, private equity, and real estate, it is the recognition of this differences that separate infrastructure as a distinct investment class.

\section{Sources of Finance and the Asset Classes}

According to Adair et al (1994) investment involves the present commitment of a capital sum for benefits to be enjoyed in the future which could be in the form of an income flow or capital gain or a combination of both thereby utilizing capitals for maximum possible return. Most institutional investors maintain a conservative investment style, trying to combine the highest return with the lowest risk level in the investment portfolio (McGreal, 1994). Investors have a number of options in terms of financial objectives, expectations and selections with respect to risk tolerance and return, these options between investments are usually referred to as asset classes. The ultimate about asset classes therefore is to provide a model structure to the numerous collections of financial instruments available for investment decision and selection to take place. Asset classes are important to investors, as each different asset class has a different risk profile and effect on portfolio performance and allocation (Finweek, 2006).

A pioneering study on the significance of asset allocation by Brinson et al (1986) has shown that asset allocation decision is a key determinant of portfolio returns (94\%), other factors are market timing (2\%) and security selection (4\%). Jahnke (1997) observes an anomaly with this analysis, stating that the focus was on explaining portfolio volatility rather than portfolio returns, instead, investors should be more concerned with the range of likely outcomes over their investment planning horizon than the volatility of returns. A study by Ibbotson and Kaplan (2000) also support that asset allocation explains about $90 \%$ of the variability of returns over time. Ho et al (2006) highlight asset allocation as an important component in balancing asset weights in a portfolio within the constraints of an investor's capital resources and investment time horizon, in order to attain the most favourable risk-return trade-off for the investor. Similarly, the Vanguard Group (2006) also identifies that strategic asset allocation, or policy allocation, is the most important determinant of total return and risk for a broadly diversified portfolio, Adair et al (1994) also assert that the optimal allocation of asset classes forms an integral part of the investment decision-making process.

This is particularly significant in determining investment performance which varies over time for different asset classes. A recent study by Scottish Widows (2009) reveals the percentage returns for various asset classes performance measured over each calendar year from 1994 to 2008. In 1994, UK property was rated best performing. However, in 2008 after the onset of the credit crunch, the performance of the UK property market was adversely affected. Investing in several asset classes which tend to have different performance characteristics therefore increases the diversification benefits which protect the investor from losses associated with just one asset class thereby reducing volatility by offsetting the falls of one asset class with the gains of another within the investment portfolio. Efficient diversification becomes a model structure for investors to sufficiently benefit from the quality performance of other asset classes.

Adair et al (1994) highlight the significance of efficient diversification to an investment portfolio; the optimal allocation of asset involves combining investment with less than perfect positive correlation between the returns of the assets involved in order to reduce risk without sacrificing the portfolio's returns. McGreal et al (2006) conjecture that the rationale for diversifying an investment portfolio is to reduce non-systematic risk, this arises from a number of sources including lease terms, operating and financial leverage, tenant mix and location. These factors are influenced by business cycles (local, regional, national and international); socio-economic trends (demographic, employment and income); and the macroeconomic factors such as levels of inflation and interest rates.

From the academic and professional perspectives Adair et al (2007) and the Australia and New Zealand (ANZ) Banking Group (2007) identify various asset classes in relation to their central characteristics as affects class ( defensive or growth), return, risk, liquidity, transparency and holding period (Table 2). 
Table 2. Key Characteristics of Asset Classes

\begin{tabular}{|l|c|c|c|c|c|c|}
\hline Asset class/type of fund & Return & Risk & Liquidity & Transparency & Holding period & Class \\
\hline Cash & Low & Low & High & High & Short/medium & Defensive \\
\hline Gilts & Low & Low & High & High & Long & Defensive \\
\hline Corporate bonds & Medium & Medium & High & High & Long & Defensive \\
\hline Property & Medium & Medium & Low & Low & Medium/long & Growth \\
\hline Equities & High & High & High & High & Short/medium & Growth \\
\hline Private equity & High & High & Low & Low & Short/long & Growth \\
\hline Hedge funds & High & High & Low & Low & Medium/long & Growth \\
\hline
\end{tabular}

Source: Adair, Berry, Hutchison and McGreal (2007), ANZ (2007)

It is arguably believed that real estate investment is a good diversifier of risk. Lee (2004) examined the risk reducing benefits of adding property to increase diversification and identified in which periods real estate helps to reduce portfolio risk. The results suggest that for $70 \%$ of the time direct real estate would have contributed little to the return performance of alternative assets. In others words, returns from direct real estate only offset the losses in the alternative asset about $30 \%$ of the time. However, this increase in performance occurs when the alternative asset showed negative returns.

A similar study by Adair, McGreal and Webb (2006) proposed that real estate tends to be a good portfolio diversifier for low- and medium-risk portfolios not only for non-securitized real estate returns as well as real estate returns from pooled property funds and real estate common stocks (securitized real estate) but have virtually no impact on the allocations for common stocks, government bonds (gilts) or inflation. However, placing this assertion in the context of a different investment climate such as the current credit crunch tends to depict a different investment performance. In the light of this, Liow and Zhu (2007) highlight that the optimal performance of real estate portfolio during a bear market (market characterized by falling prices for securities) regime show a different outcome from those of the bull market (market characterized by rising prices for securities) system, with higher correlations between various real estate security markets' returns in the bear market regime than in the bull market regime.

Therefore taking into consideration the effect of market variations due to regime shifts might result in sub-optimal asset allocation and inaccurate portfolio performance measurement.

Closely related to the real estate asset class is infrastructure which is already emerging as a separate asset class. According to Newell et al (2009) the last ten years have witnessed an unprecedented growth and performance of investment in listed infrastructure and the global infrastructure sub-sectors, basically outperforming other asset classes such as global stocks and the real estate revealing the average annual returns for one-, three-, five and ten-year holding periods for global infrastructure and the various global asset classes at the fourth quarter of 2006. As a result of the foregoing, it is not unexpected to see property companies both at the international and domestic levels, including infrastructure in their investment portfolio cutting across a wide range of infrastructure investment subsectors such as toll roads (defensive assets with long-term concessions and pricing usually linked to inflation); railways (passenger railway performance driven by passenger volume and modest sensitivity to economic conditions) and electricity (global supplydemand outlook remains positive) (Cohen \& Steers, 2009)

It can be construed that investment in infrastructure is cost-effective, considering that infrastructure consists of services for which the user is prepared to pay; investments may be sourced through government privatization processes, sales of businesses already in private hands, or by constructing and subsequently operating the asset, although subject to varying scales of regulatory supervision and market risk. There is also a growing application of Public-Private Partnerships (PPP) especially for social infrastructure investments such as affordable housing, schools, public transport and hospitals (RREEF, 2005), typically consisting of partnerships between the public and private sectors under which the government continues to provide the core service while the private sector builds, owns, operates and maintains the physical assets and facilities.

Evidence of the Private Finance Initiative (PFI) introduced in the UK in 1992 is a clear indication of a Public Private Partnership model used to procure projects involving the construction of assets needed to deliver public services cutting across intricate and major public sector infrastructure projects such as in transportation, schools, defence, leisure, culture, housing and public health infrastructure. As of March 2008, over 625 PFI projects had been signed with a total 
capital value of $\$ 90.4 \mathrm{Bn} .{ }^{1}$

There tend to be a consensus among the key players in infrastructure financing and provision that infrastructure as an asset class has reached a new phase in its growth and expansion, this relates to the benefits of increasing investment returns derived from the maintenance and upgrading of existing assets and the broad range of opportunities included in the construction of new assets (PEI, 2009). Despite the current global financial crises, institutional investors tend to remain attracted to the infrastructure asset class for its quality as a valuable diversifier capable of delivering meaningful risk-adjusted returns over the long term. Reinforcing the above claim, Lindeiner and Eckermann (2009) highlight that the attraction of infrastructure in an environment of an intense global recession and extended volatility on financial markets lies in the resilient characteristics and the portfolio benefits that it offers across the business cycle. In periods of accelerating inflation, infrastructure assets tend to have structures in place such as the road tariff that allow for an annual adjustment to the consumer or retail price index.

\section{Infrastructure Funds}

The continued motivation and increasing interest among investors in the infrastructure sector is established by the increasing growth of infrastructure funds. According to Orr (2007) infrastructure funds refer to entities that are committed to offering a portfolio of securities and making direct financial investments in the management, ownership and/or operation of infrastructure and utilities, usually cutting across a broad range of assets such as power (renewables, coalfired, gas turbine and nuclear), water (treatment and distribution), transportation (airports, ports, roads, parking lots and rail (gas distribution, electricity transmission, Communications assets such as broadcasting towers and materials handling facilities such as docks. The Fund primarily invests in equity securities and can also invest in hybrid or debt securities issued by infrastructure entities. The Fund may also invest in derivatives, largely for currency hedging and other risk purposes (Macquarie Investment Management Limited, 2009).

Infrastructure funds generally involve an asset-manager model, where a sponsoring manager establishes a separate publicly traded entity to own infrastructure assets while contracting out management functions to the sponsor (Lawrence and Stapledon, 2008). A number of attractive features such as access to a developing alternative investment class, diversification benefits, returns and income growth combine to attract investors to the infrastructure funds. The incomes generated by infrastructure assets can be predictable, as they usually operate in environments with low levels of competition and high barriers to entry. For growth-orientated funds, the absence of stable income in the near-term is compensated with capital growth in the medium term, as it uses excess funds to expand its portfolio. On the other hand, some Infrastructure Funds have more mature and established assets that are generating steady income streams (ASX, 2008). Eshwar (2006) highlight that infrastructure funds are virtually diversified funds, spreading risk across investment in stocks related to capital goods, construction, roads and power.

However, Infrastructure funds are not exclusively a novel phenomenon; its history dates back to 1990 initiated by Australia's Macquarie Group Limited commonly referred to as 'Macquarie', with over $£ 30.2$ billion under management at year end-2008 (Lannen, 2009), several other infrastructure funds (Table 3) have also been created across the globe.

Table 3. Largest Infrastructure Funds, June 2007

\begin{tabular}{|l|l|c|c|c|}
\hline \multicolumn{1}{|c|}{ Fund Name } & \multicolumn{1}{|c|}{ Parent } & $\begin{array}{c}\text { Amount Raised } \\
\text { or Target (MM) }\end{array}$ & $\begin{array}{c}\text { Vintage year } \\
\text { or State }\end{array}$ & $\begin{array}{c}\text { Geographic } \\
\text { Target }\end{array}$ \\
\hline GS Infrastructure1 & Goldman Sachs & $\$ 6,500$ & 2006 & Global \\
\hline Macquarie European Infrastructure Fund 11 & Macquarie Bank & $E 4,600$ & 2006 & Europe \\
\hline Macquarie Infrastructure Partners & Macquarie Bank & $\$ 4,000$ & 2007 & North America \\
\hline Alinda Capital partners 1 & Alinda Capital partners & $\$ 3,000$ & In Market & North America \\
\hline AIG Highstar 111 & AlG Highstar & $\$ 3,000$ & In Market & Global \\
\hline Citigroup Infrastructure Investors & $\begin{array}{l}\text { Citigroup Alternative } \\
\text { Investors }\end{array}$ & $\$ 3,000$ & In Market & $\begin{array}{c}\text { Developed } \\
\text { Markets }\end{array}$ \\
\hline
\end{tabular}

\footnotetext{
1 Kearsarge Global Advisors in coordination with Abertis, Allen \& Overy LLP, Barclays Capital, Carlyle Infrastructure Partners, Chadbourne \& Parke LLP, Citi Infrastructure Investors (CII), Credit Suisse, Debevoise \& Plimpton, Freshfields Bruckhaus Deringer, Fulbright \& Jaworski, Mayer Brown, McKenna Long \& Aldridge LLP, Merrill Lynch, Morgan Stanley, RREEF, RBC Capital Markets, Scotia Capital, and UBS.
} 


\begin{tabular}{|l|l|c|c|c|}
\hline Morgan Stanley Infrastructure & Morgan Stanley & $\$ 3,000$ & In Market & Global \\
\hline RREEF Pan-European Infrastructure Fund & Deutsche-RREEF & $\mathrm{E} 2,000$ & In Market & Europe \\
\hline Abraaj Infrastructure and Growth Capital Fund & Abraaj Capital2,000 & $\$ 2,000$ & In Market & Global \\
\hline Babcock \& Brown Infrastructure Fund & Babcock \& Brown & $\$ 2,000$ & In Market & North America \\
\hline Gulf One Infrastructure Fund & Gulf One Bank & $\$ 2,000$ & In Market & Middle East \\
\hline IDFC Private Equity Fund 11 & IDFC Private Equity & $\$ 2,000$ & In Market & India \\
\hline Infracapital Partners & Prudential Plc & $£ 1,000$ & In Market & Europe \\
\hline
\end{tabular}

Source: Probitas Partners (2007)

Infrastructure as an asset class has seen a worldwide growth and increase in the number of infrastructure funds despite the contraction affecting several other asset classes such as hedge funds, mutual funds and private equity funds as a result of the credit crisis. According to KPMG (2008) the aggregate worldwide infrastructure fund value exceed US\$312 billion in 2007, rising from US\$225 billion in 2006, and almost two thirds of this coming from new entrants. According to Bliss and Braham (2009) there has been a dramatic increase in the number and classes of infrastructure investors, with a majority of funds raised through bank-sponsored funds, followed by 'funds of funds', private equity funds and independent funds, around 30 dedicated funds were launched and $\$ 40$ billion to $\$ 60$ billion of equity capital raised for investing in the developed markets of Europe and North America between 2006 and 2007 (Jain, 2008).

The progress has been particularly rapid in Europe. In January 2003 there were just ten funds but by July 2007 this number had risen to 58. And the value of European acquisitions had grown from less than US $\$ 2$ billion in 2003 to over US\$44 billion in 2006 (KPMG International, 2008). Buttressing further, the 2008 Preqin Infrastructure Review reveals that unlisted infrastructure has shown signs of progressive growth since 2004 and the fundraising has grown by an astonishing proportion of $429 \%$ in 2 years (2006-2007). In 2007 a total of $\$ 34.9 \mathrm{bn}$ was raised (Figure 1), up from $\$ 6.6 \mathrm{bn}$ raised in 2005 , and $\$ 13.2 \mathrm{bn}$ has been raised already by the middle of 2008 .

Figure 1. Growth of Unlisted Infrastructure Fund Market, 2004-2008 YTD

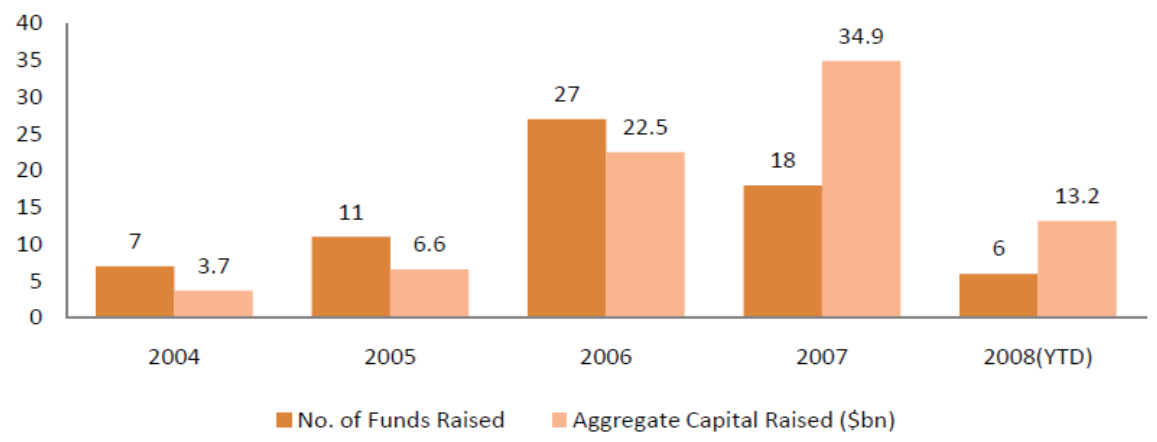

Source: Preqin (2008)

The increasing magnitude of unlisted infrastructure funds has seen its transformation from being a sector within a real estate portfolio into a separate asset class. Many investors now treat the sector completely independently to other private equity and unlisted fund investments, with a significant $47 \%$ of active investors in the asset class establishing a separate allocation for infrastructure, while $43 \%$ include infrastructure funds in their private equity portfolio and $10 \%$ include it in their real assets portfolio (Preqin, 2008).

However, McCrosson and Cleal (2009) perceive a likely short term difficulty with sustaining an increasing level of growth and fund-raising as a result of major institutional investors such as pension and insurance funds reconsidering their asset-class allocations in the light of revised equity and fund valuations. Conversely, in the light of the current financial climate, evidence suggests that these institutional investors may increase allocations to infrastructure investment, following the hitches faced by other counterpart alternative investments.

On a second assailment to the development of infrastructure funds, Rocker (2009) argue that infrastructure funds were not entirely unaffected by the economic meltdown evidenced by some sharp reduction in infrastructure funds market capitalisation growth which began in 2007 (Figure 2) and reported cases of failing performance even by pioneering funds such as Macquarie Group, and has had to raise AUD\$1 billion in new capital and Babcock \& Brown fell into voluntary 
administration in March 2009. Similarly, Davis (2008) point to the restructuring of strategies among infrastructure fund operators as a result of substantial declines in the market value of many infrastructure funds listed on the ASX. This however led to a series of criticisms of the infrastructure fund model among financial market and business analyst.

Figure 2. Infrastructure Funds market capitalisation growth

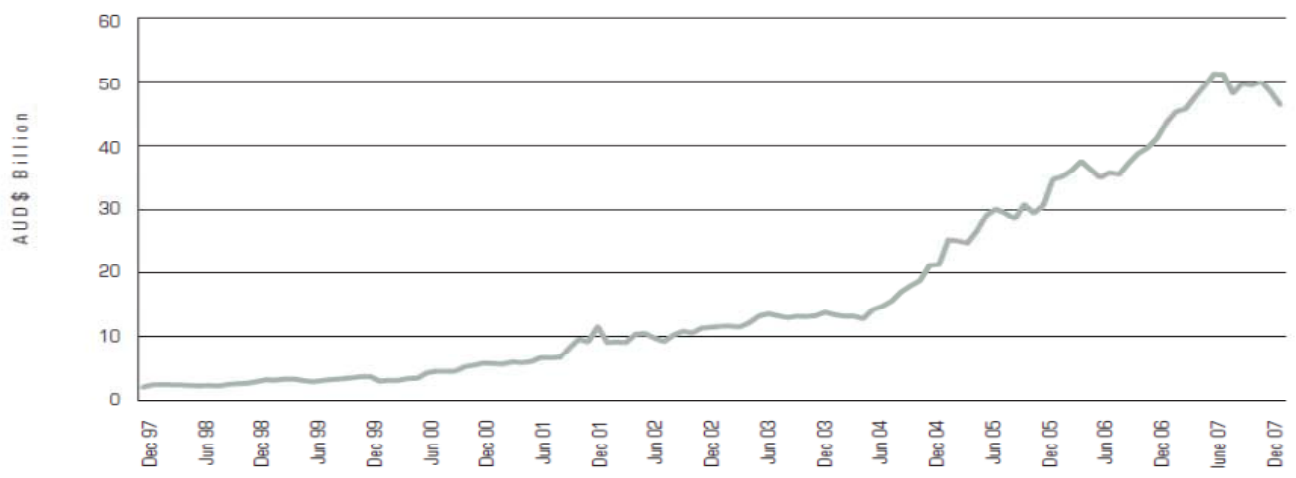

Source: ASX (2008)

The economic meltdown however does not yet seem to be excessively affecting the rise of global infrastructure funds as it appears that the appetite for such mechanisms is still strong, as demonstrated by the recent 2008 launch of funds from ING (US\$2 billion) and Morgan Stanley (US\$4 billion) (KPMG International, 2008). Recent deals further demonstrate a growing interest in infrastructure funds especially among institutional investors, for instance the Australia's Macquarie Bank has raised $\$ 10.3$ billion from pension funds and other investors expected to be invested in assets in Europe and North America through two separate infrastructure funds; Macquarie European Infrastructure Fund II will invest \$6.3 billion in infrastructure assets within Europe while Macquarie Infrastructure Partners has $\$ 4$ billion for investments in North America (Reuters, 2009). It therefore show that there are different geographical drive and strategic characteristics among infrastructure funds operators, according to Probitas Partners (2007) most of the funds are focused on developed countries even within those funds that have global investment mandates. However, it should be noted that there are a significant number of funds focused on investing in India and the Middle East. While most of the infrastructure funds are sponsored by large financial institutions, some adopt opportunistic investment strategies; opportunistically investing across the infrastructure risk/return spectrum. Those funds focused on emerging economies are more focused on Greenfield investments while those focused on developed markets tend to be more focused on Brownfield and Rehabilitated Brownfield investments (Probitas Partners, 2007), thereby creating significant opportunities for investment in infrastructure.

There are several outlets of opportunities for both individual and institutional investors to share of the benefits derived from commitment to infrastructure investment. Standard \& Poor's (2008) broadly classify these opportunities into unlisted and listed infrastructure funds. There key differences (Table 4) lie in areas of the nature of investments, expenses, liquidity, access to funds and level of diversification.

Table 4. Two Major Methods of Investing In Infrastructure

\begin{tabular}{|c|c|c|}
\hline Features & Infrastructure Fund & $\begin{array}{l}\text { Listed Infrastructure } \\
\text { Assets }\end{array}$ \\
\hline Nature of investment & Active investment in a few projects & Exposure to broad market \\
\hline Expenses & Moderate-typically $0.7-1 \%$ plus performance fees & Low-usually $0.5 \%-0.6 \%$ \\
\hline Liquidity & Low-Investments usually locked up for a certain period & High- Investments trade on an exchange \\
\hline Access & $\begin{array}{l}\text { Low- Funds typically open only to qualified or } \\
\text { institutional investors }\end{array}$ & High-securities can be bought on the open market \\
\hline Diversification & $\begin{array}{l}\text { Low to moderate-Funds can diversify, subject to due } \\
\text { diligence and time constraints }\end{array}$ & $\begin{array}{l}\text { High- typically encompass different infrastructure } \\
\text { clusters and countries }\end{array}$ \\
\hline Beta Risk & Low & high \\
\hline
\end{tabular}

Source: Standard \& Poor's (2008) 
Several other investment channels range from diversified multi-asset funds with a proportion of their assets in infrastructure holdings, to stocks in individual projects and various forms of debt instruments (Bloch, 2009). Idzorek and Armstrong (2009) highlight three primary methods of gaining exposure to infrastructure assets as: Direct-lt typically requires significant amounts of capital for a single purchase; Private Equity Funds/Partnerships -These invest directly in infrastructure assets on behalf of their shareholders or partners and Listed Infrastructure Vehicles -These are collections of publicly traded stocks whose business is directly related to infrastructure assets.

According to Russell (2009) previously the main sphere of influence among larger institutional investors were in the direct or unlisted infrastructure investment, the maturing and promising global listed market has given a wider range of investors easier access and opportunity to this emerging asset class. Listed funds are publicly traded infrastructure funds and usually specialise in specific sub-sectors of infrastructure. However, some recent funds have begun to invest across diversified infrastructure sectors and geographies (CAI Research, 2008), pointing out clearly the attractive and overall uniqueness surrounding infrastructure assets such as degree of regulation, monopolistic operations, predictable cash flows, strong total returns and low long-term correlations with the broader equity and fixed income markets. Given its inherent defensive attributes, the asset class can provide investors with inflation- and recession-protected cash flows. The capacity to pass on higher costs to end users, as well as the ability to conserve real revenue growth, further enhances the asset class's likeliness to outperform in down markets (Cohen \& Steers, 2009). In unfolding the several benefits attached to owning part of a professionally managed portfolio of infrastructure assets, investors should however be mindful of the intrinsic risk associated with infrastructure fund investment such as liquidity risk, infrastructure sector risk, sovereign risk, market risk, counterparty risk and concentration risk.

Particularly infrastructure sector risk and the possibility of undesirable events in the global infrastructure market to impact the performance and returns of the infrastructure Fund (Macquarie Investment Management Limited, 2009). The investment strategies of the infrastructure fund operators are therefore vital not only in expediently positioning for the current financial climate but also in harnessing the possibilities of sustainability of the funds performance thereby reinforcing investors' confidence and motivation for increased commitment to infrastructure investment. Consolidating this assertion, Abu et al (2009) highlight the rationale for expansion of infrastructure funds including positive multiplier effects, efficient capital deployment, political risk cover, deal flow agglomeration, and encouragement of clean energy.

\section{Conclusion}

This paper demonstrates that infrastructure investment has all it takes to be a separate asset class. Though a hybrid asset, sharing certain features with other asset classes, it is a unique asset with distinctive features. The attractive and resilient characteristics of infrastructure have fascinated a growing involvement of the private sectors especially institutional investors to the asset class. Several factors have been identified as driving/motivating the emergence of infrastructure as a separate asset class, apart from the benefits of increasing investment returns derived from investment in infrastructure resources, there are structures in place for a guaranteed sustainability of investors' stake in there commitment to investment in infrastructure. Moreover, it is a universal principle that no nation will be economically stable without proper functioning infrastructure systems. The entire life cycle of infrastructures whether social or economic infrastructures, existing or new, generally have significant effect on economic growth. The increasing demand of infrastructure as an essential daily resources and the pressure of growing public budgetary deficit coupled with a mounting growth of global population, will continue to compel the public sector to increasingly create room for larger involvement of the private sector in financing and investing in infrastructure.

However, further investigation of infrastructure investment performance is necessary, though this can be encumbered as a result of dearth of empirical data considering the fact that infrastructure has always been the exclusive reserve of the public sector and only recently there is a growing involvement of the private sector. The paper, while recognizing the broad range of contributions from previous research, admits that infrastructure investment analysis is not yet as scrupulous compared to traditional asset classes such as stocks and bonds. Nevertheless, with the increasing involvement of the private sector and the increasing interest in infrastructure investment, a more rigorous investigation of infrastructure performance analysis is deliverable in the future. 


\section{References}

ABS (2001) Government Financial Statistics, Australia (5512.0) Retrieved 2nd October, 2001 from www.abs.gov.au

Abu C., Orr R.J. and Settel D. (2009) "Multilaterals and Infrastructure Funds: A New Era", The Journal of Structured Finance, Winter 2009.

Adair A., Berry J, Hutchison N. and Mcgreal S.(2007) Attracting Institutional Investment into Regeneration: Necessary Conditions for Effective Funding; Journal of Property Research, September 2007, 24(3) 221-240

Adair A., McGreal S. and Webb J.R (2006) Journal of Real Estate Portfolio Management; May-Aug 2006; 12, 2; ABI/INFORM Global

Adair A.S., Berry J.N. and McGreal W.S. (1994) Investment Decision Making: A Behavioural Perspective Journal of Property Finance Vol. 5 No. 4, 1994, pp. 32-42

ANZ (2007) Asset Classes Australia and New Zealand Banking Group Limited L3267n/0807

ASX-Australian Security Exchange (2008) Infrastructure Funds LMI Fact Sheet, ASX Limited ABN 98008624691

Beeferman L.W. (2008) Pension Fund Investment in Infrastructure: Pensions and Capital Stewardship Project Labor and Worklife Program Harvard Law School; Occasional Paper Series - No.3 December, 2008 http://www.law.harvard.edu/programs/lwp /pensions/publications/occpapers/occasionalpapers3.pdf

Bliss N. and Braham E. (2009) European infrastructure investors: back to the classics Freshfields Bruckhaus Deringer LLP March 2009 25265 http://www.freshfields.com/publications/pdfs/2009/feb09/25265.pdf

Bloch B. (2009) Build Your Portfolio with Infrastructure Investments http://www.investopedia.com/articles/mutualfund/07 /infrastructure.asp?viewed=1

CAl Research (2008) Investing in Developed Country Private Infrastructure Funds Citigroup Global Markets Inc., July 2008 http://billcara.com/assets/korvus/inv_dev_country.pdf

Cohen \& Steers, Inc (2009) Global Listed Infrastructure: A Compelling Investment February 2009

Davis K.T. (2008) Listed Infrastructure Funds: Funding and Financial Management (December 28, 2008). Available at http://papers.ssrn.com/sol3/papers.cfm?abstract id=1337473

Deutsche Bank (2007) AG Infrastructure Investment Introductory Notes - November 2007 http://www.uksip.org/assets/166 IAgostino_D.pdf

Deutsche Bank (2007) AG Infrastructure Investment Introductory Notes - November 2007

Finkenzeller K. and Dechant T. (2009) Infrastructure - A new Dimension of Real Estate?An Asset Allocation Analysis; the 2009 annual European Real Estate Society conference 24-27 June 2009; Stockholm

Grimsey D and Lewis M.K (2002) Evaluating the Risks of Public Private Partnerships for Infrastructure Projects; International Journal of Project Management 20 (2002) 107-118

Hobbs P. and Lowik L. (2007) Infrastructure Investing: The Journal of the Investment Property Forum Issue No. 6 April 2007.

Idzorek T. and Armstrong C. (2009) Infrastructure and Strategic Asset Allocation: Is Infrastructure an Asset Class? January 2009 http://corporate.morningstar.com/ib/documents/MethodologyDocuments/IBBAssociates/Infrastructure SAA.pdf

Inderst G. (2009), „Pension Fund Investment in Infrastructure“, OECD Working Paper on Infrastructure and Private Pensions No.32.

Invesco (2008) Private Sector Investment Fuels Infrastructure Expansion in Emerging Markets; Invesco Perspective; September 2008

KPMG International (2008) The Rise and Rise of Infrastructure Funds http://us.kpmg.com/Rutus_Prod/Documents /12/Rise_Infrastructure_Funds.pdf

Kohn L.A ((2008) Infrastructure- The Next Asset Class; Pension Fund Performance Guide- Local Authority Edition 2008.

Lawrence M. and Stapledon G. P. (2008) Infrastructure Funds: Creative Use of Corporate Structure and Law - But in Whose Interests?(February 2008). U of Melbourne Legal Studies Research Paper No. 314. Available at SSRN: http://ssrn.com/abstract=1092689

Lindeiner B. and Eckermann H.(2009) Infrstructure- Defensive Portfolio Diversification;

Partners Group Research Flash, March, 2009

Liow K.H. and Zhu H. (2007) Regime switching and asset allocation Evidence from international real estate security markets; Journal of Property Investment \& Finance Vol. 25 No. 3, 2007 pp. 274-288

Macquarie (2007) Infrastruction Research Report, May 2, 2007

Macquarie Infrastructure Company (2009) Introduction to Infrastructurehttp://www.macquarie.com/mic/aboutus/intro_infrastructure.htm

McGreal S., Adair A .and Webb J.R. (2009) Optimal Diversification in U.S./U.K. Private Real Estate Only Portfolios: The Good, the Bad, and the Uncertain; Journal of Real Estate Portfolio Management, Jan-Mar 2009

McGreal S., Webb J.R., Adair A. and Berry J.(2006)Risk and Diversification for Regeneration/Urban Renewal Properties: Evidence from the U.K.Journal of Real Estate Portfolio Management, Jan-Apr 2006

Mills J. (2007) Investment in the UBS Infrastructure Fund Report of the Director of Finance, IT and Trading; Investment \& Pension Fund Committee 11 May 2007

Morgan Stanley (2009) The Infrastructure Opportunity: Repair, Build and Stimulate; Investment focus Investment Management Morgan Stanley Research February 2009

Moteff J., Copeland C., and Fischer J. (2003) Critical Infrastructures: What Makes an Infrastructure Critical? Congressional Research Service The Library of Congress Updated January 29, 2003 http://www.fas.org/irp/crs/RL31556.pdf

Newell G. and Peng H.W. (2008) the Role of U.S. Infrastructure in Investment Portfolios; Journal of Real Estate Portfolio Management Vol. 14, No. 1, 2008 
Newell G. and Peng H.W (2008) European infrastructure Investment: A Valuable Addition to the Mixed-Asset Portfolio Findings in Built and Rural Environments June 2008 research FiBRESERIES

Newell G., Chau K.W. and Wong S.K (2009) The significance and performance of infrastructure in China; Journal of Property Investment \& Finance Vol. 27 No. 2, 2009

OECD (Organisation for Economic Co-Operation and Development) Policy Brief 2008; Infrastructure to 2030 http://www.oecd.org/dataoecd/24/1/39996026.pdf

OECD Report: Infrastructure To 2030: Global investment needshttp://www.macquariefunds.co.uk/uk/mfg/acrobat/infrastructure_oecd study.pdf

Orr R.J. (2007). "The rise of infra funds." Project Finance International - Global Infrastructure Report 2007, Supplement, June, 2007, pp 2-12.http://crgp.stanford.edu/publications/articles_presentations/Orr_01_Infra_funds_2007pfie.pdf

Parker G. (2008) Investing in Asian Infrastructure: The S\&P Asia Infrastructure Index Jüly 2008 http://www2.standardandpoors.com /spf/pdf/index/Investing_Asian_Infrastructure_0708.pdf

PCA (2007) Infrastructure Research Report; Pension Consulting Alliance, Inc.Judy Chambers June 2007

Phillips, Hager \& North (PH\&N) (2007) Investing in Infrastructure; The Foundations of a "New" Asset Class Phillips, Hager \& North ("PH\&N") July 22, 2007

RREEF (2007) Performance Characteristics of Infrastructure Investments RREEF Research August 2007

Reuters (2008) Sovereign funds may have biggest impact on alternative assets Thu May 22, 2008 http://www.reuters.com larticle/fundsFundsNews/idUSHKG14044720080522

Rocker T. (2009) Frontiers in finance supplement | Infrastructure funds: down but far from out; KPMG International June 2009 Financial Services http://www.kpmg.com/SiteCollectionDocuments/Frontiers-supplements-infrastructure-funds.pdf

Russell OpenWorld (2009) Listed infrastructure investing Issue date: January 2009 http://www.openworldinvesting.com/PDFs /Strategy_Brochures/Brochure_Listed_Infrastructure_Investing_2008_11.pdf

Standard \& Poor's, (2008) Listed Infrastructure Assets - A Short Guide to Listed Infrastructure Investing and the S\&P Global Infrastructure Index Standard \& Poor's, April 2008. http://www2.standardandpoors.com/spf/pdf/index/Gbl_Infrastructure Primer_April.pdf

Stevens B. (2008) Global Infrastructures to 2030: London, OECD/International Futures Programme29 April 2008

Timotijevic D. (2008) Infrastructure on the defensive: The performance of infrastructure in a credit crisis 28 October 2008 accessed 23/06/2009 http://www.mercer.com/summary.htm?siteLanguage=100\&idContent=1326325

Value Added (2006) Infrastructure: The Road Less Traveled; A Newsletter for the MOSERS Board of Trustees Volume 8 Issue 5 November 2006

Williams M. (2009) Infrastructure Investment Opportunities; Cliffwater LLC January 27, 2009 http://www.cliffwater.com/research /Cliffwater\%200verview\%20of\%20Infrastructure\%20Investing\%20-\%20Jan\%2027\%202009.pdf

World Bank (2006) Financing Infrastructure: Addressing Constraints and Challenges Finance and Private Sector Development Unit South Asia Region June 2006 